\title{
Serological and molecular detection of Theileria equi in horses from Sinop, Mato Grosso state, Brazil*
}

\section{Detecção sorológica e molecular de Theileria equi em equinos oriundos de Sinop, Mato Grosso, Brasil}

\author{
Suyane Nayara Garcia Socoloski Bonadimann, ${ }^{* *}$ Matheus Dias Cordeiro, ${ }^{* * *}$ \\ José Luis Rodríguez Bautista, ${ }^{* * *}$ Jenevaldo Barbosa da Silva, ${ }^{* * * *}$ Rafael Romero Nicolino, ${ }^{* * * * *}$ \\ Adivaldo Henrique da Fonseca, ${ }^{* * *}$ Luciano Bastos Lopes**
}

\begin{abstract}
Equine piroplasmosis is the most important tick-borne disease to affect horses in Brazil. Theileria equi is one of the causative agents of equine piroplasmosis. Chronic cases are expected, in which the animals show no apparent signs of infection and remain asymptomatic but constitute a source of the infectious agent that ticks can spread. This study was conducted across 81 ranches located in the municipality of Sinop, State of Mato Grosso, Brazil. A sample calculation was performed to estimate the apparent prevalence of $T$. equi among horses. A total of 1,853 animals were included in the sampling analysis based on the information available from the Institute of Agricultural and Livestock Defense of Mato Grosso State. The serological analysis of 367 serum samples using an indirect enzyme-linked immunosorbent assay (ELISA) to detect anti-T. equi antibodies revealed that 337 animals were positive, representing a frequency of $90.70 \%$. The molecular analysis to amplify the EMA-1 gene showed positivity in 20 of 89 tested samples. The fragments of four samples were sequenced and analyzed to determine their similarities to sequences from other species, based on sequences deposited at GenBank. All showed $100 \%$ similarity with $T$. equi. Our study represents the first report of $T$. equi antibodies among the equids in north-central region of Mato Grosso, revealing the widespread distribution of seropositive animals.
\end{abstract}

Keywords: Equine piroplasmosis, theileriosis, serology, PCR.

\section{Resumo}

A piroplasmose equina é a doença transmitida por carrapatos mais importante em cavalos no Brasil. Theileria equié um dos agentes causadores da piroplasmose equina. São esperados casos crônicos, nos quais os animais não apresentam sinais aparentes de infecção e permanecem assintomáticos, mas constituem uma fonte de infecção e disseminação por carrapatos. Este estudo foi realizado em 81 fazendas localizadas no município de Sinop, Estado de Mato Grosso, Brasil. Um cálculo amostral foi realizado para estimar a prevalência aparente de T. equi entre cavalos. No total, 1.853 animais foram incluídos na análise amostral com base nas informações disponíveis no Instituto de Defesa Agropecuária do Estado de Mato Grosso. A análise sorológica de 367 amostras de soro por meio de ensaio imunoenzimático indireto (ELISA) para detecção de anticorpos anti-T. equi revelou que 337 animais eram positivos, representando uma frequência de 90,70\%. A análise molecular para o gene EMA-1 mostrou positividade em 20 das 89 amostras testadas. Os fragmentos de quatro amostras foram sequenciados e analisados para determinar suas semelhanças com sequências de outras espécies, a partir das sequências depositadas no GenBank. Todos mostraram 100\% de similaridade com $T$. equi. Nosso estudo representa o primeiro relato de anticorpos contra $T$. equi entre os equídeos na região centro norte de Mato Grosso, revelando a ampla distribuição de animais soropositivos.

Palavras-chave: Piroplasmose equina, teileriose, sorologia, PCR.

\section{Acknowledgments}

We would like to express our gratitude to the Conselho Nacional de Desenvolvimento Científico e Tecnológico - CNPq (A.H.F. 312169/2017-5), Coordenação de Apoio ao Aperfeiçoamento de Pessoal de Nível Superior - CAPES, Instituto de Defesa Agropecuária do Estado de Mato Grosso | INDEA.

\section{Introduction}

Theileria equi is one of the causative agents of equine piroplasmosis, representing one of the primary animal health issues that constrain the health of equine populations found in tropical and sub-tropical regions worldwide (ONYICHE et al., 2019). Equine theileriosis is a tick-transmitted disease that can

*Recebido em 18 de maio de 2021 e aceito em 11 de julho de 2021.

${ }^{* *}$ Animal Science, Federal University of Mato Grosso - UFMT, Alexandre Ferronato, $n^{\circ} 1200$, Setor Industrial, Sinop, MT, Brazil.

*** Laboratório de Cultivo de Células e Hemoparasitos, Federal Rural University of Rio de Janeiro-UFRRJ, Rodovia 465, Km 07, s/n Zona Rural, Seropédica, RJ, Brazil.

${ }^{* * * *}$ Federal University of Jequitinhonha and Mucuri Valleys - UFVJM, Agronomic Sciences Institute, University Av., $n^{\circ} 1000$ - Unaí, MG, Brazil.

${ }^{* * * * *}$ Federal University of Minas Gerais | UFMG, Dep. Of Veterinary Epidemiology, Belo Horizonte - MG, Brazil.

******Embrapa Agrossilvipastoril. Av. Embaúbas, 567, Caixa Postal 343, Sinop - Mato Grosso, Brazil. Correspondent author*, luciano.lopes@embrapa.br | https://orcid.org/0000-0002-9433-521X. 
affect horses and other equids. In conjunction with Babesia caballi, this tick-transmitted piroplasm can cause hemolytic anemia during the acute phase of the disease (CAMPOS et al., 2019). T. equi is primarily transmitted by tick species belonging to several genera, such as Rhipicephalus, Dermacentor, and Hyalomma (WISE et al., 2014). However, in some countries such as the USA and Japan, Amblyomma mixtum and Haemaphysalis longicornis have also been implicated in $T$. equi transmission (SCOLES and UETI, 2015). Infected animals become pathogenic carriers and may serve as a source of infection through tick vectors for a long time, allowing the subsequent transmission of $T$. equi to other equid hosts. Therefore, equine theileriosis is considered a highly relevant disease with global distribution and is considered endemic in some regions with tropical and subtropical weather, where at least one competent tick vector exists. The infection rates among domestic horses in endemic regions may reach as high as $60 \%$, and in some regions, more than $90 \%$ of animals can be infected with either $T$. equi alone or in combination with B. caballi (SCOLES and UETI, 2015).

The clinical disease can occur in acute, sub-acute, or chronic forms. Commonly, acute and sub-acute cases are characterized by marked hemolysis and subsequent anemia. Other symptoms observed in these two disease forms include fever, anorexia, anemia, jaundice, mucosal surface petechiae, hemoglobinuria, tachypnea, weakness, abortion, and even death. The symptoms present in sub-acute cases are typically milder than those observed in acute cases and are accompanied by weight loss and intermittent fever. Chronic cases are the most common condition, in which animals present with no apparent signs and remain asymptomatic but constitute a source of the infectious agent that can be spread by ticks (VIANNA et al., 2014; Wise et al., 2014).

The diagnosis of equine theileriosis is commonly challenging because the symptoms are often nonspecific. $T$. equi infections can often confuse Babesia caballi infections due to the clinical and sub-clinical similarities between the symptoms associated with these two infections. Blood smears can be used, in some cases, mainly when parasitemia is evident. Even when the visualization of the merozoite form is possible, a conclusive diagnosis must be performed using a more accurate method because the morphologies of this form of $T$. equi and $B$. caballi are often similar. Serological and molecular methods are more accurate identification methods (MANS et al., 2015).

In Brazil, several seroepidemiological and detection studies using molecular techniques have been conducted in different regions to establish the distribution, prevalence, and risk factors associated with $T$. equi infections in horses and other equids (BALDANI et al., 2010; GUIMARÃES et al., 2016; MACHADO et al., 2012; MINERVINO et al., 2020; NOGUEIRA et al., 2017; PROCHNO et al., 2014; QUINTANA NIZOLI et al., 2008; VIEIRA et al., 2018; VIEIRA et al., 2013).

Because the horse population in the north of Mato Grosso State is relevant, and appropriate climate conditions for tick vectors characterize the region, determining the distribution and prevalence of equine theileriosis in this region is necessary to understand the disease epidemiology and impacts on animal health. The primary aim of this study was to determine the seroprevalence of $T$. equi and perform the PCR-based detection of $T$. equi in horses from different rural locations in the municipality of Sinop, MT, Brazil. The study was performed to establish whether any associations existed between the pathogenic prevalence and any intrinsic animal features or health management practices.

\section{Materials and Methods}

This study was conducted across 81 ranches located in the municipality of Sinop, State of Mato Grosso, Brazil. According to Köppen criteria as Tropical wet and dry (Aw), the local climate was classified with rainfall concentrated in the summer/autumn and the dry season in winter/spring (Stape et al. 2014). The average annual temperature is $25.5^{\circ} \mathrm{C}$, with $20.2^{\circ} \mathrm{C}$ minimum and $33.0^{\circ} \mathrm{C}$ maximum temperatures. The mean annual relative air humidity is $70 \%$, with annual precipitation of $2250 \mathrm{~mm}$.

Figure 1: Sampling spots in Sinop municipality, MT

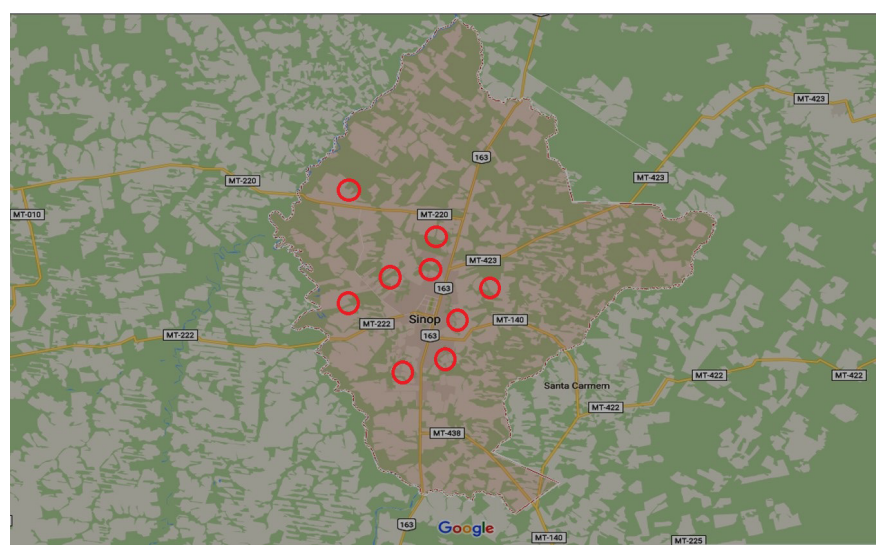

Sample calculation was performed using EpiTools (AusVet Animal Health Services, 2016) to determine the necessary sample size required to estimate the apparent prevalence of T. equi in horses. A total of 1,853 animals were included in the sampling analysis, based on the information available from the Institute of Agricultural and Livestock Defense of Mato Grosso State (INDEA). According to INDEA dataset, 412 farms in Sinop were involved in the breeding, raising, or using horses for any activity in 2015 . We used $50 \%$ as the expected prevalence when performing the calculations, as no a priori information currently exists regarding the epidemiological status of equine theileriosis in the Sinop region. The maximum error expected was $10 \%$, and the confidence level defined for the study was $95 \%$. On farms with fewer than five horses, all animals were sampled, whereas on farms with more than five animals, samples were collected from approximately $20 \%$ of the herd.

\section{Epidemiological information}

An epidemiological questionnaire was designed to obtain information regarding the ranches and animals (Madureira et al., 2009). The herd-level variables that were investigated as putative risk factors and included on the questionnaire: the predominant breed (Quarter Horse, crossbreeds, and other breeds), gender (male and female), age (up to four years, four to 15 years, and older than 15 years), use (leisure, sport, reproduction, and work), and health management, with a focus on ectoparasite control. The self-reported questionnaire was answered during an interview in the same day of blood sampling. 


\section{Sample collection}

The horse ranches were selected through a convenience sampling method due to difficulties associated with local accessibility; however, blood samples were taken randomly within the farms, irrespective of horse breed, gender, use, or age. Sampling was first performed between 30/07/2013 and 08/08/2013 (samples 01 - 213), and then between 18/09/2015 and 12/07/2016 (samples 214 - 434).

Samples were collected by venipuncture (vacutainer tubes and needles; Becton Dickinson Vacutainer Systems, Franklin Lakes, NJ), later processed at the Laboratory of Infectious Disease at the Federal University of Mato Grosso by centrifugation (3000 $\mathrm{G}$ for $15 \mathrm{~min}$.). Serum samples were then aliquoted into micro tubes and stored at $-20^{\circ} \mathrm{C}$ until serological analysis. For the nested polymerase chain reaction (PCR), others blood samples were collected from 89 horses (89/367) into tubes containing ethylenediaminetetraacetic acid (EDTA), which were aliquoted into micro tubes and stored at $-20^{\circ} \mathrm{C}$.

\section{Laboratory analysis}

Serology for $T$. equi was performed at the Laboratory of Parasitic Diseases at the Federal Rural University of Rio de Janeiro using the enzyme-linked immunosorbent assay (ELISA) technique (BALDANI et al., 2004). We used samples from our serum bank as positive and negative controls during these experiments. The cut-off value was established as described by Frey et al. (1998), using $99 \%$ confidence intervals.

The molecular analysis was performed using the nested-PCR technique on 89 blood samples. We extracted DNA from the samples and controls using a commercial kit (Wizard ${ }^{\text {TM }}$ Genomic DNA Purification Kit, PROMEGA ${ }^{\odot}$ ), as recommended by the manufacturer's instructions. The extracted DNA was analyzed individually using the forward primer EMA-1F (5'-GCATCCATTGCCATTTCGAG-3') and the reverse primer EMA-1R (5'-TGCGCCATAGACGGAGAAG-3'), which were designed to amplify a region of the $T$. equi equi merozoite antigen $1(E M A-1)$, according to a methodology that was previously described by Alhassan et al. (2005). The expected size PCR products were cleaned using ExoSAP-IT (Affymetrix ${ }^{\circledR}$ ) and sequenced using a capillary-type Sanger platform in an $\mathrm{ABI}$ 3730 DNA Analyzer (Applied Biosystems, Life Technologies ${ }^{\circledR}$ ). The sequences that were generated were compared against published data using the NCBI Nucleotide BLAST program.

The apparent prevalence of $T$. equi was estimated by defining a specific weight for each sampled unit based on each animal's herd size relative to the studied population, following the method described by Dargatz and Hill (1996) and Dohoo et al. (2003). Stata software 14 (Stata Corporation, College Station, TX) was used to perform data management and statistical analyses. The adjusted prevalence rate ratio (PRR) and 95\% confidence interval $(\mathrm{Cl})$ for each variable were estimated using Poisson regression. Variables with $p$-values $\leq 0.15$ in the univariate analyses and those with known, plausible, biological associations with $T$. equi positivity were included in the multivariate analysis, to which a backward selection approach was applied ( $p<0.05)$.

\section{Results}

The indirect ELISA for the detection of anti-T. equi antibodies in the 367 tested serum samples revealed that 337 animals were positive, resulting in a frequency of $90.70 \%$.

The molecular analysis designed to amplify the EMA-1 gene found in $T$. equi, showed positivity in 20 of 89 samples. The fragments from two samples were sequenced and analyzed to determine their similarities with the sequences of other species, based on the sequences deposited at GenBank, and all showed $100 \%$ similarity with T. equi. The partial nucleotide sequences generated were deposited in GenBank with access numbers MW815402 and MW815404.

After performing the univariate analyses, those variables with $p$-values $\leq 0.15$ were included in the multivariate analysis, including sex, origin, leisure use, sport, reproduction, work, more than one use, total horses on the property, use of ticks, and species consortium. Neither sex nor the age of the horse (younger than four years, from four to 15 years, and older than 15 years) was significantly associated $(p>0.05)$ with $T$. equi seropositivity. Breed (Quarter Horse, crossbreed, and other breeds) was not associated with $T$. equi seropositivity. Using the backward selection method, only those variables with $p$-values < 0.05 were considered significant and remained in the final model.

\section{Discussion}

Equine theileriosis has long been considered an important and endemic disease for the equine industry in Brazil because it has widely spread throughout the equid population in several regions of the country, which has been demonstrated by extensive previous studies using a variety of diagnostic methods (BALDANI et al., 2010; BARBOSA et al., 1995; CAMPOS et al., 2013; CAMPOS et al., 2014; GUIMARÃES et al., 2016; HEIM et al., 2007; MACHADO et al., 2012; MINERVINO et al., 2020; PECKLE et al., 2018; PECKLE et al., 2013; QUINTANA NIZOLI et al., 2008; VIEIRA et al., 2018).

To our best knowledge, this study represents the first serological and molecular study to examine equine theileriosis by evaluating the epidemiology of $T$. equi across 81 farms in northern region of Mato Grosso, Brazil. Laboratory diagnostic findings, in conjunction with associations between disease prevalence and various farm features and management practices, will contribute to our understanding of the epidemiology of this disease throughout the country.

Concerning the serological survey, $90.7 \%$ of the animals were seroreactive. This high proportion of seroreactive horses likely indicates the endemic status of this disease in the region of study. These results agree with other findings all over Brazil, where high infection prevalence rates support the endemic status of this disease in the study regions. This finding is also in concordance with other serological studies that have been performed using ELISA or indirect ELISA tests to examine T. equi in Brazil, which have shown high prevalence ranges, from $21.6 \%$ to $81.09 \%$ (CAMPOS et al., 2013; GOLYNSKI et al., 2008; KERBER et al., 2009; MACHADO et al., 2012; MINERVINO et al., 2020; PROCHNO et al., 2014; SANTOS et al., 2011; VIEIRA et al., 2013). 
This high seroprevalence may be common to regions where the disease is considered highly endemic, particularly when comparing the high infection frequency identified in this study with previous serological study findings that have used other techniques, such as the indirect fluorescent antibody test (IFAT), for which serological prevalence values have ranged from $22.1 \%$ to $100 \%$ (BARBOSA et al., 1995; QUINTANA NIZOLI et al., 2008; GOLYNSKI et al., 2008; BALDANI et al., 2010; GUIMARÃES et al., 2016; NOGUEIRA et al., 2017; CAMPOS et al., 2019). Even higher percentages of seroreactive horses, reaching as high as $100 \%$ of the tested equine population, have previously been observed in other regions, including Jaboticabal, São Paulo (BALDANI et al., 2010) and rural areas of the State of Rio de Janeiro (BARBOSA et al., 1995).

In contrast, only $22.7 \%$ of $T$. equi-infected horses were identified by the PCR amplification of the EMA-1 gene, based on 89 blood samples. This finding is in concordance to other epidemiological studies conducted in other Brazilians'regions, such as Mato Grosso do Sul (HEIM et al., 2007; KIM et al., 2008; CAMPOS et al., 2019), Minas Gerais (HEIM et al., 2007), Rio Grande do Sul (QUINTANA NIZOLI et al., 2008; VIEIRA et al., 2018), São Paulo (HEIM et al., 2007; BALDANI et al., 2010; MACHADO et al., 2012), Rio de Janeiro (PECKLE et al., 2013), Maranhão (NOGUEIRA et al., 2017), and Paraná (PROCHNO et al., 2014), for which the prevalence values have ranged between $13.4 \%$ to $96 \%$.

Besides, this study highlights risk factors associated with the property features, breed management, and animal characteristics. Regional differences in the seropositivity and infection rates identified among equine populations should be carefully analyzed because of farm-specific management practices, climate conditions, topography, the population densities of horses and other animals, the dynamics of the tick populations. Moreover, the use of differing serological and PCR approaches and techniques may mask the true disease prevalence.

According to the univariate analysis, neither sex nor the horse's age was associated $(p>0.05)$ with $T$. equi seropositivity. On the other hand, the breed was not associated with $T$. equi seropositivity, which other authors previously described (ABUTARBUSH et al., 2012; CAMPOS et al., 2013; PECKLE et al., 2018). Furthermore, the same authors showed a significant association between the use of horses for more than one activity and the frequency of $T$. equi positivity, which was also observed in this study.

Additionally, in the bivariate analysis, no significant association was found between $T$. equi ELISA-seropositivity and horses used for breeding $(p \geq 0.05)$, which agrees with the findings of previous studies performed in the State of Rio de Janeiro in 2013 (CAMPOS et al., 2013).
The use of horses primarily for specific purposes, including recreational activities and work, were factors that were associated with $T$. equi infection $(p \leq 0.001)$. Other studies reported similar factors to be significantly associated with $T$. equi seropositivity or PCR and qPCR positivity in horses (ABUTARBUSH et al., 2012; PECKLE et al., 2018). In contrast, recreational activities were not associated with seropositivity in a study performed in a municipality of the State of Rio de Janeiro in 2013 (CAMPOS et al., 2013). In this study, horses used for sport were associated with $T$. equi infection positivity $(p \geq 0.1)$, which was also identified by other investigations to be a significant factor associated with T. equi infection (ABUTARBUSH et al., 2012; PECKLE et al., 2013). A significant association between $T$. equi infections and farms where acaricide treatments were applied for tick control was also observed $(p \leq 0.01)$.

That is the first report to describe a serological and molecular survey on equine theileriosis in a relevant number of horses for the northern region of the State of Mato Grosso. Infection positivity was also associated with certain intrinsic and extrinsic features of the animals evaluated.

According to the results of this study, the region is likely in an endemic disease state. The endemic situation of equine theileriosis in the northern region of the State of Mato Grosso highlights the importance of using appropriate methods for disease control and the control of potential disease-transmitting tick populations.

Our results showed the highest seropositive frequency value compared with previous reports. Because none of the tested animals were clinically sick or exhibiting symptoms compatible with clinical piroplasmosis, the endemic stability of the disease in the evaluated horse population is likely.

The presence of $T$. equi antibodies in equids revelated the widespread distribution of seropositive animals, indicating that the endemicity of equine theileriosis is well-established in the study region, and the prevalence in the equine population agrees with other studies performed Brazil.

\section{Conclusion}

The high seroprevalence rate found for $T$. equi in the evaluated horse population emphasized that active surveillance and appropriate control methods are critical for monitoring equine health status. The present study contributes to the understanding of the epidemiology of equine theileriosis in Brazil. Further research on equine theileriosis should be conducted at the regional and national levels to provide baseline information regarding epidemiology, tick vectors, and control methods.

\section{Funding}

The research leading to these results received funding from CAPES/FAPEMAT | Financial support for Suyane Bonadimann.

\section{Conflict of interest statement}

None of the authors of this paper has a financial or personal relationship with other people or organizations that could inappropriately influence or bias the paper's contents. 


\section{Ethics approval}

The authors whose names are listed above certify that they have not committed any willful act of abuse or cruelty or neglected animal rights included in this study. Participants provided their verbal informed consent for animal blood sampling as well as for the related survey questions. All the procedures recommended by OIE to apply the diagnosis test were used as described in the methodology.

\section{References}

AUSVET ANIMAL HEALTH SERVICES. EpiTools epidemiological calculators. 2016. http://epitools.ausvet.com.au/content. php?page=home. Accessed 09 Dec 2016.

Abutarbush, S., Alqawasmeh, D., Mukbel, R., AlMajali, A. Equine babesiosis: seroprevalence, risk factors and comparison of different diagnostic methods in Jordan. Transboundary and Emerging Diseases, 59, 72-78, 2012.

Baldani, C.D., Machado, R.Z., Botteon, P.d.T.L., Takakura, F.S., Massard, C.L. An enzyme-linked immunosorbent assay for the detection of IgG antibodies against Babesia equi in horses. Ciencia Rural, 34, 1525-1529, 2004.

Baldani, C.D., Nakaghi, A.C.H., Machado, R.Z. Occurrence of Theileria equi in horses raised in the Jaboticabal microregion, São Paulo State, Brazil. Revista Brasileira de Parasitologia Veterinaria, 19, 228-232, 2010.

Barbosa, I.P., Böse, R., Peymann, B., Friedhoff, K. Epidemiological aspects of equine babesioses in a herd of horses in Brazil. Veterinary Parasitology, 58, 1-8, 1995.

Campos, C.H.C., Prado, R.F.S., Guimarães, A., Silva, A.T., Baldani, C.D., Cordeiro, M.D., Pires, M.S., Peixoto, M.P., Santos, H.A., Machado, R.Z., Fonseca, A.H., Massard, C.L. Aspectos epidemiológicos e soroprevalência de Theileria equi em equinos de uso militar no município de Resende, estado do Rio de Janeiro, Brasil. Revista Brasileira de Medicina Veterinária, 35, 106-112, 2013.

Campos, J.B., André, M.R., Gonçalves, L.R., Freschi, C.R., Santos, F.M., de Oliveira, C.E., Piranda, E.M., de Andrade, G.B., Macedo, G.C., Machado, R.Z. Assessment of equine piroplasmids in the Nhecolândia sub-region of Brazilian Pantanal wetland using serological, parasitological, molecular, and hematological approaches. Ticks and tick-borne diseases, 10, 714-721, 2019.

Dargatz, D.S., and Hill, G.W. Analysis of survey data, Preventive Veterinary Medicine, 28, 225-237, 1996.

Frey, A., Di Canzio, J., Zurakowski, D. A statistically defined endpoint titer determination method for immunoassays. Journal of Immunology Methods, 221: 35-41, 1998.

Golynski, A.A., Fernandes, K.R., Baldani, C.D., Golynski, A.L., Madeiro, A.S., Machado, R.Z., Botteon, P.D.T.L., Massard, C.L. Estudo soroepidemiológico da Babesia equi em eqüinos do estado do Rio Grande do Sul, Brasil determinado pelos testes de Imunofluorescência Indireta e ELISA. Revista Brasileira de Parasitologia Veterinaria, 17, 317-321, 2008.

Guimarães, A.M., Bruhn, F.R.P., Ribeiro, M.J.M., Rosa, M.H.F., de Mello Garcia, A., da Rocha, C.M.B.M., de Assis Rocha, I. Prevalence and risk factors of Theileria equi infection in horses in Minas Gerais, Brazil. Veterinary Parasitology: Regional Studies and Reports, 3, 18-22, 2016.

Heim, A., Passos, L.M., Ribeiro, M.F., Costa-Júnior, L.M., Bastos, C.V., Cabral, D.D., Hirzmann, J., Pfister, K. Detection and molecular characterization of Babesia caballi and Theileria equi isolates from endemic areas of Brazil. Parasitology research, 102, 63-68, 2007.
Kerber, C.E., Labruna, M.B., Ferreira, F., De Waal, D.T., Knowles, D.P., Gennari, S.M. Prevalence of equine Piroplasmosis and its association with tick infestation in the State of São Paulo, Brazil, 2009. Revista Brasileira de Parasitologia Veterinaria, 18, 1-8.

Kim, C.-m., Blanco, L.B.C., Alhassan, A., Iseki, H., Yokoyama, N., Xuan, X., Igarashi, I. Diagnostic real-time PCR assay for the quantitative detection of Theileria equi from equine blood samples, 2008. Veterinary parasitology, 151, 158-163.

Machado, R., Toledo, C., Teixeira, M., André, M., Freschi, C., Sampaio, P. Molecular and serological detection of Theileria equi and Babesia caballi in donkeys (Equus asinus) in Brazil. Veterinary parasitology, 186, 461-465, 2012.

Madureira, R.C., Rangel, C.P., Scofield, A., Barbosa, N., J.D., Fonseca, A.H. Sorologia para Borrelia burgdorferi em equinos da Ilha de Marajó e município de Castanhal, Pará, Brasil. Revista Universidade Rural. Série Ciências da Vida, 29, 9-15, 2009.

Mans, B., Pienaar, R., Latif, A. A review of Theileria diagnostics and epidemiology. International Journal for Parasitology: Parasites and Wildlife, 4, 104-118, 2015.

Minervino, A.H.H., Torres, A.C., Moreira, T.R., Vinholte, B.P., Sampaio, B.M., Bianchi, D., Portela, J.M., Sarturi, C., Marcili, A., Barrêto Júnior, R.A. Factors associated with the prevalence of antibodies against Theileria equi in equids of Western Pará, Brazil. Transboundary and emerging diseases 67, 100-105, 2020.

Nogueira, R.d.M.S., Silva, A.B., Sato, T.P., Sá, J.C.d., Santos, A.C.G.d., Amorim Filho, E.F., Vale, T.L.d., Gazêta, G.S. Molecular and serological detection of Theileria equi, Babesia caballi and Anaplasma phagocytophilum in horses and ticks in Maranhão, Brazil. Pesquisa Veterinaria Brasileira 37, 1416-1422, 2017.

Onyiche, T.E., Suganuma, K., Igarashi, I., Yokoyama, N., Xuan, X., Thekisoe, O. A review on equine piroplasmosis: epidemiology, vector ecology, risk factors, host immunity, diagnosis and control. International Journal of Environmental Research and Public Health 16, 1736., , 2019. doi: 10.3390/ijerph16101736.

Peckle, M., Pires, M.S., da Silva, C.B., da Costa, R.L., Vitari, G.L.V., Senra, M.V.X., Dias, R.J.P., Santos, H.A., Massard, C.L. Molecular characterization of Theileria equi in horses from the state of Rio de Janeiro, Brazil. Ticks and tick-borne diseases, 9: 349-353, 2018.

Peckle, M., Pires, M.S., dos Santos, T.M., Roier, E.C.R., da Silva, C.B., Vilela, J.A.R., Santos, H.A., Massard, C.L. Molecular epidemiology of Theileria equi in horses and their association with possible tick vectors in the state of Rio de Janeiro, Brazil. Parasitology Research, 112, 2017 - 2025, 2013.

Prochno, H.C., Scorsin, L.M., De Melo, F.R., Baldani, C.D., Falbo, M.K., Aquino, L.C.T.d., Lemos, K.R.. Seroprevalence rates of antibodies against Theileria equi in team roping horses from central-western region of Paraná. Revista Brasileira de Parasitologia Veterinaria, 23, 85-89, 2014.

Quintana Nizoli, L., Mendes Götze, M., Rodrigues Félix, S., Silva Da Silva, S., Nogueira, W., Eduardo, C. Frequency of seropositive equines for Theileria equi in the Southern Rio Grande do Sul State, Brazil. Parasitologia Latinoamericana, 63, 46-50, 2008. 
Santos, T.M.d., Roier, E.C.R., Santos, H.A., Pires, M.S., Vilela, J.A.R., Moraes, L.M.d.B., Almeida, F.Q.d., Baldani, C.D., Machado, R.Z., Massard, C.L. Fatores associados à Theileria equi em equídeos de duas microrregiões do Rio de Janeiro, Brasil. Revista Brasileira de Parasitologia Veterinaria, 20, 235241, 2011.

Scoles, G.A., Ueti, M.W. Vector ecology of equine piroplasmosis. Annual review of entomology, 60, 561-580, 2015.

Vianna, A.M., Gonçales, R.A., Lara, A.P.d.S.S.d., Pinto, L.d.S., Nizoli, L.Q., Leite, F.P.L., 2014. Expressão heteróloga da EMA2 (equi merozoite antigen) de Theileria equi em Pichia pastoris com potencial utilização em imunobiológicos. Ciencia Rural, 44, 1830-1836.
Vieira, M.I.B., Costa, M.M., de Oliveira, M.T., Gonçalves, L.R., André, M.R., Machado, R.Z. Serological detection and molecular characterization of piroplasmids in equids in Brazil. Acta tropica, 179, 81-87, 2018.

Vieira, T.S., Vieira, R.F., Finger, M.A., Nascimento, D.A., Sicupira, P.M., Dutra, L.H., Deconto, I., Barros-Filho, I.R., Dornbusch, P.T., Biondo, A.W. Seroepidemiological survey of Theileria equi and Babesia caballi in horses from rural and from urban areas of Paraná State, southern Brazil. Ticks and tick-borne diseases, 4: 537-541, 2013.

Wise, L.N., Pelzel-McCluskey, A.M., Mealey, R.H., Knowles, D.P. Equine piroplasmosis. Veterinary Clinics: Equine Practice, 30, 677-693, 2014. 